\title{
Hubungan High Sensitivity C-Reactive Protein dan Tekanan Darah pada Anak dengan Riwayat Berat Lahir Rendah Kecil Masa Kehamilan
}

Adi Suryadinata Krisetya, Adrian Umboh, Jose M. Mandei

Bagian Ilmu Kesehatan Anak Fakultas Kedokteran Universitas Sam Ratulangi/RSUP Prof. Dr. R. D. Kandou, Manado

Latar belakang. Anak dengan riwayat berat lahir rendah (BLR) kecil masa kehamilan (KMK) memiliki peningkatan risiko menderita hipertensi dan gangguan kardiovaskular di kemudian hari. High sensitivity C-reactive protein (hs-CRP) memengaruhi kerusakan pembuluh darah yang mengakibatkan peningkatan tekanan darah.

Tujuan. Menganalisis hubungan hs-CRP dengan berat lahir dan tekanan darah pada anak dengan riwayat BLR KMK.

Metode. Penelitian dengan desain potong lintang dilakukan dari bulan Oktober - Desember 2018 di Manado. Kriteria inklusi adalah anak dengan riwayat BLR KMK, lahir pada tahun 2004-2009 di Rumah Sakit Umum Pusat Kandou, berdomisili di Manado, memiliki catatan medis lengkap, status gizi baik, dan mendapat persetujuan dari orang tua. Kriteria eksklusi adalah anak yang memiliki riwayat penyakit ginjal, sakit dan mengonsumsi obat-obatan dalam 2 minggu terakhir. Pengukuran Hs-CRP digunakan metode imunonephelometric dengan Dade Behring kit. Data dianalisis menggunakan korelasi Pearson dan uji regresi linier sederhana. Hasil. Total 40 anak dengan riwayat BLR KMK terdiri dari 16 anak laki-laki dan 24 anak perempuan. Rerata berat lahir adalah 2338,75 gram dan rerata kadar hs-CRP adalah 1,3158 mg/L. Terdapat hubungan negatif antara hs-CRP dan berat lahir ( $\mathrm{r}=-0,275$; $\mathrm{p}=0,043)$, hubungan positif antara hs-CRP dan tekanan darah sistolik (TDS) $(\mathrm{r}=0,559 ; \mathrm{p}<0,0001)$, dan juga antara hs-CRP dengan tekanan darah diastolik (TDD) $(\mathrm{r}=0,451 ; \mathrm{p}=0,002)$.

Kesimpulan. Terdapat korelasi negatif antara hs-CRP dan berat lahir. Nilai hs-CRP yang tinggi berhubungan dengan TDS dan TDD yang lebih tinggi pada anak berusia 9 - 14 tahun dengan riwayat BLR KMK. Sari Pediatri 2020;21(5):289-94

Kata kunci: high sensitivity c-reactive protein, tekanan darah, berat lahir rendah, kecil masa kehamilan

\section{Correlation Between High Sensitivity C-Reactive Protein and Blood Pressure in Children Born Low Birth Weight and Small for Gestational Age}

Adi Suryadinata Krisetya, Adrian Umboh, Jose M.Mandei

Background. Low birth weight (LBW) and small for gestational age (SGA) children have an increased risk of developing hypertension and cardiovascular diseases during adult life. High sensitivity C-Reactive Protein (hs-CRP) is associated with endothelial damage that will cause an increase in blood pressure.

Objective. To analyze for a possible association between hs-CRP and blood pressure in children who were born low birth weight and small for gestational age.

Methods. We conducted a cross-sectional study from October to December 2018. Inclusion criteria were children who were born LBW and SGA in 2004-2009 at Kandou General Hospital, resided in Manado, had complete medical records, good nutritional status, and parents consented to their participation. Exclusion criteria were children who had renal disease, sick and taking medications prior to enrollment. Hs-CRP was measured using immunonephelometric methods with The Dade Behring kit. Data were analyzed using Pearson correlation and simple linear regression test.

Result. A total of 40 children with LBW and SGA history consisted of 16 boys and 24 girls. The mean birth weight is 2338.75 grams and the mean hs-CRP level is $1.3158 \mathrm{mg} / \mathrm{L}$. There was a negative correlation between hs-CRP and birth weight $(\mathrm{r}=-0.275$; $\mathrm{p}$ $=0.043)$, a positive correlation between hs-CRP and systolic blood pressure $(\mathrm{r}=0.559 ; \mathrm{p}<0.0001)$, as well as hs-CRP and diastolic blood pressure ( $\mathrm{r}=0.451 ; \mathrm{P}=0.002)$.

Conclusion. Hs-CRP and birth weight have a negative correlation. Higher hs-CRP is associated with higher systolic and diastolic blood pressure in 9 to 14-year-old children who were LBW and SGA at birth. Sari Pediatri 2020;21(5):289-94

Keywords: high sensitivity c-reactive protein, blood pressure, low birth weight, small for gestational age

Alamat korespondensi: Adi Suryadinata Krisetya. Bagian Ilmu Kesehatan Anak Fakultas Kedokteran Universitas Sam Ratulangi, RSUP Prof Dr.R.D. Kandou. Jl. Raya Tanawangko, Manado, Indonesia. E-mail: adikrisetya@gmail.com

Sari Pediatri, Vol. 21, No. 5, Februari 2020 
$\mathrm{P}$ rotein C-reaktif merupakan suatu reaktan fase akut yang disintesis hati sebagai respon terhadap sitokin yang dilepaskan oleh jaringan yang rusak. CRP juga dihasilkan oleh sel dinding pembuluh darah seperti sel endotel, sel otot polos, dan jaringan lemak. Produksi CRP dikontrol oleh interleukin-6 yang merupakan suatu sitokin inflamasi.

Berat lahir rendah didefinisikan oleh Organisasi Kesehatan Dunia (WHO) sebagai berat badan lahir kurang dari 2500 gram. Bayi berat lahir rendah (BBLR) dapat dibedakan atas bayi prematur dan bayi yang mengalami pertumbuhan janin terhambat (PJT). ${ }^{1,2}$ Dalam perkembangannya, BBLR memiliki tingkat morbiditas jangka panjang yang tinggi, seperti hipertensi, penyakit ginjal stadium akhir, resistensi insulin dan penyakit kardiovaskuler. ${ }^{3,4}$ Anak dengan riwayat BLR mengalami gangguan nefrogenesis dan inflamasi kronik jangka panjang yang menyebabkan peningkatan produksi CRP. Mekanisme bagaimana CRP memengaruhi kerusakan pembuluh darah berhubungan dengan angiogenesis, kerusakan endotel, stress oksidatif, dan remodeling pembuluh darah dimana seluruh proses tersebut akan menyebabkan peningkatan tekanan darah.

Penelitian ini bertujuan untuk menganalisis hubungan hs-CRP dengan berat lahir dan tekanan darah pada anak dengan riwayat BLR KMK.

\section{Metode}

Penelitian ini menggunakan rancangan penelitian observasional analitik korelatif dengan pendekatan potong lintang. Penelitian dilakukan di Kota Manado pada bulan Oktober 2018 - Desember 2018. Sampel penelitian adalah anak berusia 9-14 tahun dengan riwayat BLR KMK yang tinggal di Kota Manado. Rumus estimasi jumlah sampel koefisien korelasi digunakan untuk menentukan jumlah sampel minimal dan didapatkan hasil sebesar 38 anak.

Dilakukan pengambilan data kelahiran dari rekam medis yang meliputi jenis kelamin dan berat badan lahir. Kriteria inklusi adalah anak dilahirkan di RSUP Prof. Dr. R. D. Kandou Manado dengan riwayat BLR KMK, memiliki catatan rekam medis, mendapat persetujuan dari orang tua, hasil pemeriksaan fisik sehat dan status gizi baik, tinggal di Kota Manado. Kriteria eksklusi adalah anak dengan riwayat hipertensi, diabetes mellitus, dislipidemia, anak sakit dan mengkonsumsi obat-obatan dalam 2 minggu terakhir, memiliki riwayat menderita penyakit ginjal, seperti sindrom nefrotik, glomerulonefritis akut atau kronik, dan gagal ginjal akut atau kronik.

Anak yang memenuhi kriteria inklusi dilakukan pengukuran tekanan darah dengan menggunakan sfigmomanometer air raksa yang telah dikalibrasi dengan ukuran manset sesuai usia. Setelah itu dilakukan pengambilan darah untuk diperiksa kadar hs-CRP; serum hs-CRP diukur dengan metode immunonephelometric dengan Dade Behring kit. Kadar hs-CRP yang dianggap menandakan adanya chronic subtle inflammation dibagi menjadi risiko rendah (hsCRP $<1 \mathrm{mg} / \mathrm{L}$ ), risiko sedang (hs-CRP $1-3 \mathrm{mg} / \mathrm{L}$ ) dan risiko tinggi (hs-CRP $>3 \mathrm{mg} / \mathrm{L}$ ).

Penelitian ini telah memperoleh kelaikan etik dari Komisi Etik Penelitian Kesehatan Fakultas Kedokteran Universitas Sam Ratulangi/RSUP Prof. Dr. R. D. Kandou Manado.

Data yang diambil tersebut dimasukkan ke dalam program perangkat lunak SPSS ${ }^{\oplus} 25$. Data dianalisa dengan koefisien korelasi Pearson dan regresi linier sederhana. Tingkat kemaknaan dalam penelitian ini dinyatakan bila $\mathrm{P}<0,05$.

\section{Hasil}

Selama rentang waktu penelitian diperoleh total sampel 184 anak dengan riwayat BLR KMK. Akan tetapi, 40 anak tidak dapat dihubungi, 26 anak pindah diluar Kota Manado, 22 orangtua anak tidak bersedia untuk ikut serta dalam penelitian, 9 anak sudah meninggal. Total sampel adalah 87 anak, 15 dieksklusi karena tidak kooperatif, 14 mengalami masalah gizi (obesitas atau gizi kurang), 12 anak sakit saat penelitian dilakukan, dan 6 anak memiliki riwayat penyakit ginjal. Total 40 sampel memenuhi kriteria inklusi dan dilakukan pemeriksaan lebih lanjut.

Karakteristik subjek penelitian tertera pada Tabel 1. Rerata berat lahir adalah 2338,75 gram dan rerata kadar hs-CRP adalah 1,3158 mg/L.

Gambar 1, 2, dan 3 menunjukkan hubungan antara hs-CRP dan berat lahir, serta hs-CRP dengan TDS dan TDD. Terdapat hubungan negatif antara hsCRP dan berat lahir $(r=-0,275 ; p=0,043)$, hubungan positif antara hs-CRP dan TDS ( $\mathrm{r}=0,559 ; \mathrm{p}=<0,0001)$, dan hubungan positif antara hs-CRP dan TDD 
Tabel 1.Karakteristik sampel

\begin{tabular}{ll}
\hline Karakteristik & $\mathrm{N}=40$ \\
\hline Jenis kelamin (\%) & $16(40)$ \\
Laki-laki & $24(60)$ \\
Perempuan & $11,05 \pm 1,34$ \\
Rerata Usia (tahun) & $2338,75 \pm 113,50$ \\
Rerata Berat Lahir (gram) & $29,63 \pm 7,25$ \\
Rerata Berat Badan (kg) & $134.50 \pm 10,62$ \\
Rerata Tinggi Badan $(\mathrm{cm})$ & $108,20 \pm 10,55$ \\
Rerata TD Sistolik $(\mathrm{mmHg})$ & $68,80 \pm 9,13$ \\
Rerata TD Diastolik $(\mathrm{mmHg})$ & $1,3158 \pm 1,15$ \\
Rerata hs-CRP (mg/L) & \\
\hline
\end{tabular}

$(\mathrm{r}=0,451 ; \mathrm{p}=0,002)$ pada anak dengan riwayat BLR $\mathrm{KMK}$.

\section{Pembahasan}

Hasil penelitian ini memperlihatkan adanya hubungan negatif bermakna antara hs-CRP pada anak riwayat BLR KMK. Hasil penelitian ini mendukung penelitian Turoni $\mathrm{dkk}^{5}$ yang melaporkan kadar hs-CRP lebih tinggi pada kelompok anak dengan riwayat BLR dibandingkan dengan kelompok kontrol. Turoni $\mathrm{dkk}^{5}$ meneliti hubungan antara fungsi endotel dan

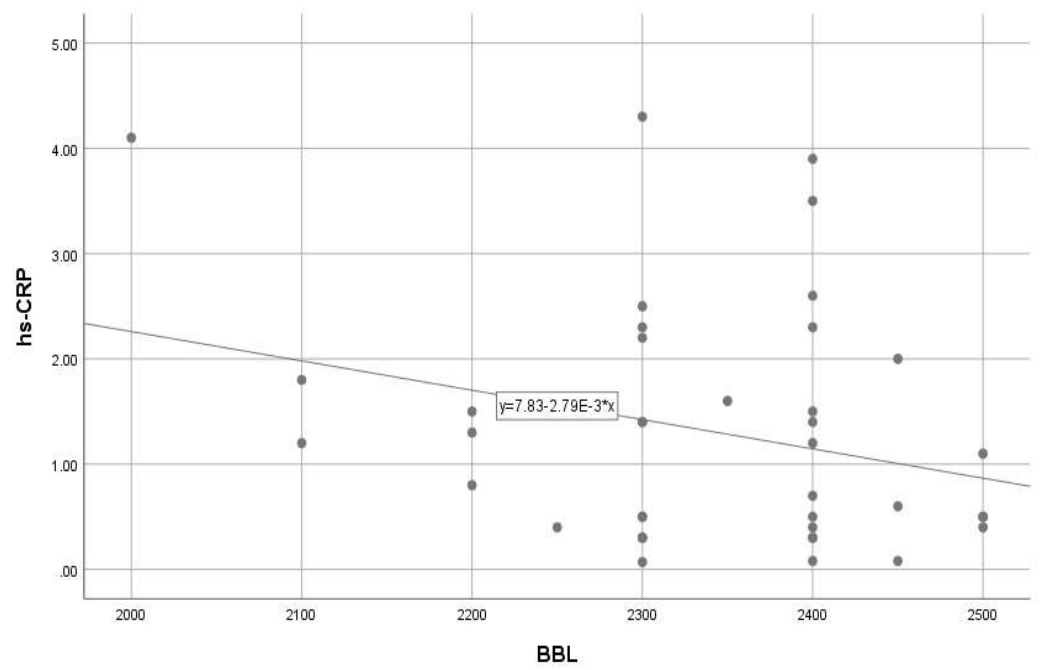

Gambar 1. Hubungan BBL dengan hs-CRP

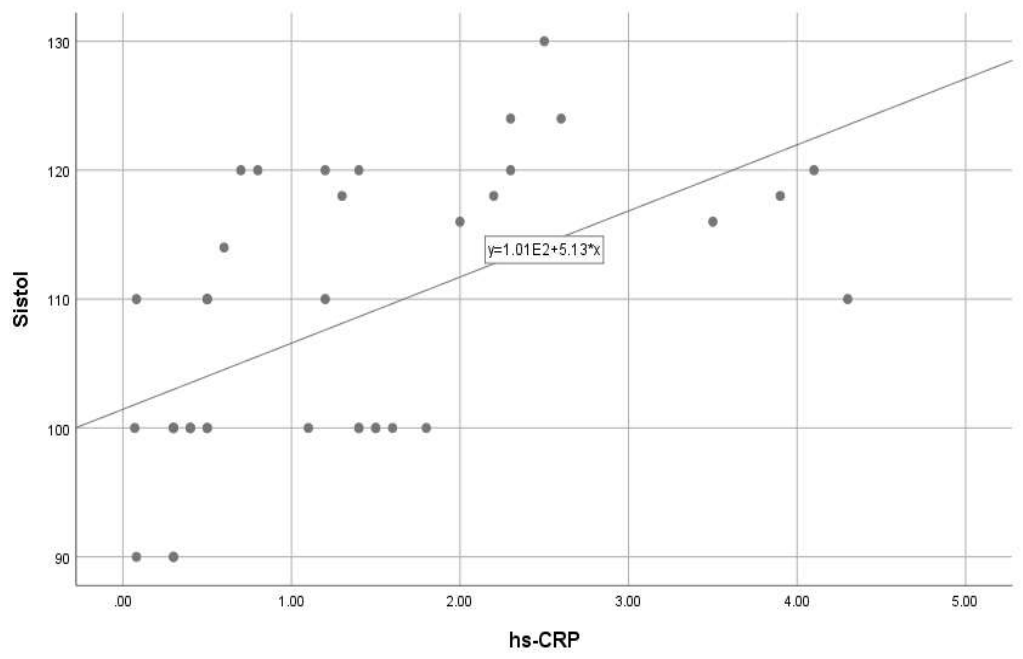

Gambar 2. Hubungan hs-CRP dengan TDS 


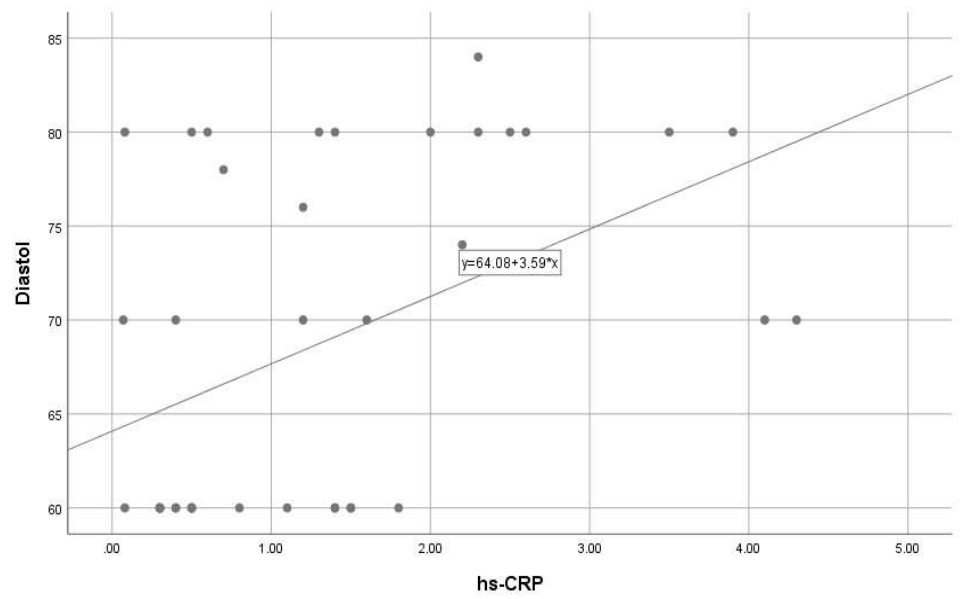

Gambar 3. Hubungan hs-CRP dengan TDD

kekakuan arteri dengan penanda (marker) dini risiko gangguan kardiovaskular pada anak berusia 4-6 tahun yang memiliki riwayat BLR. Mereka juga memperoleh hasil kelompok BLR mengalami penurunan fungsi endotel dibandingkan dengan kontrol. Penurunan fungsi endotel merupakan tanda awal dari timbulnya penyakit kardiovaskular di kemudian hari.

Kadar Hs-CRP tidak hanya dianggap sebagai penanda risiko kardiovaskular, tetapi peningkatannya juga menandakan kerusakan kardiovaskular. ${ }^{5}$

Pembentukan dan perkembangan ginjal yang sempurna pada janin biasanya terjadi sampai usia kehamilan 36 minggu dan setelah lahir tidak akan terjadi pembentukan nefron-nefron baru lagi. Pembentukan nefron intrauterin sangat dipengaruhi oleh pertumbuhan janin intrauterin yang meliputi nutrisi maternal, vitamin, terjadinya infeksi intrauterin, paparan terhadap antibiotik, merokok, dan alkohol. ${ }^{6}$

Brenner $\mathrm{dkk}^{7}$ mengemukakan bahwa gangguan terhadap pertumbuhan dan perkembangan ginjal intrauterin yang mengakibatkan berkurangnya jumlah nefron berkontribusi terhadap terjadinya hipertensi di kemudian hari. Konsep ini kemudian dikenal sebagai Brenner hypothesis atau teori nephron-underdosing. Bayi BLR memiliki korelasi dengan terjadinya gangguan ginjal dan penurunan jumlah nefron saat lahir. ${ }^{6}$

Hasil penelitian tentang hubungan antara hsCRP anak riwayat BLR KMK dengan tekanan darah, menunjukkan bahwa semakin tinggi/peningkatan nilai hs-CRP berhubungan dengan peningkatan TDS dan TDD pada anak dengan riwayat BLR KMK.

Penelitian kami mendukung studi oleh Wasilewska $\mathrm{dkk}^{9}$ pada anak berusia 10-19 tahun dengan pre- hipertensi dan hipertensi. didapatkan nilai hs-CRP pada kelompok anak tersebut lebih tinggi dibandingkan dengan kelompok kontrol dan nilai hs-CRP lebih tinggi pada kelompok hipertensi dibandingkan dengan kelompok prehipertensi . Nilai hs-CRP berkorelasi positif dengan semua pengukuran tekanan darah terkecuali TDD yang diukur pada saat malam hari.

Mekanisme bagaimana CRP memengaruhi kerusakan pembuluh darah kemungkinan berhubungan dengan angiogenesis, kerusakan endotel, stress oksidatif, dan remodeling pembuluh darah. Inflamasi dianggap sebagai mekanisme kunci dalam patogenesis aterosklerosis dan proses inflamasi juga bermakna terhadap perkembangan hipertensi arteri, gagal jantung, kelainan katup, serta fibrilasi atrium. Sel-sel inflamasi meningkatkan aktivitas metabolik pada dinding pembuluh darah, membuat media lebih asam yang pada gilirannya mempercepat apoptosis. Dengan mengaktifkan sistem angiotensin-aldosteron, reseptor angiotensin-I, dan angiotensin-II, CRP mencetuskan aktivitas proaterogenik angiotensin yang secara langsung dan tidak langsung merangsang modifikasi struktural dan fungsional dinding arteri, remodeling vaskular dan jantung, pengerasan pembuluh darah, peningkatan resistensi pembuluh darah perifer, mengganggu mekanisme regulasi tekanan darah arteri. Induksi CRP mengaktivasi matrix metalloproteinase (MMP) yang menyebabkan kerusakan kolagen pada sel-sel endotel dan makrofag serta menekan inhibitor MMP jaringan. ${ }^{10}$

Penelitian oleh Turoni $\mathrm{dkk}^{5}$ mendapatkan kelompok BLR tidak menunjukkan perbedaan bermakna dengan kelompok kontrol, baik dalam nilai rata-rata atau persentase berat badan, IMT, tinggi, lingkar pinggang, 
TDS, dan detak jantung. Pada TDS, meskipun parameter ini tetap dalam batas normal, kelompok BLR menunjukkan peningkatan bermakna dalam nilai rata-rata dan persentil. Korelasi positif antara TDS dan TDD hanya didapatkan pada kelompok BLR. Hasil ini sesuai dengan penelitian kami yang mendapatkan adanya korelasi positif antara TDS dan TDD.

Lande $\mathrm{dkk}^{11}$ melakukan studi potong lintang mengenai peningkatan tekanan darah, ras/etnis, kadar CRP pada anak dan remaja berusia 8-17 tahun. Mereka mendapatkan hasil dari total 6112 anak, anak dengan kadar CRP $\geq 3 \mathrm{mg} / \mathrm{L}$ memiliki TDS yang lebih tinggi dibandingkan dengan anak dengan kadar CRP $\leq 3$ $\mathrm{mg} / \mathrm{L}$ (109 vs $105 \mathrm{mmHg}$ ) dan TDD tidak berbeda antara kedua kelompok.

Studi oleh Rondo dkk ${ }^{12}$ di Brazil pada 459 anak berusia 5-8 tahun melaporkan hasil hubungan positif antara hs-CRP dan jenis kelamin, lingkar pinggang, $(\mathrm{P}<0,001$ dan tekanan darah sistolik . Namun, berlawanan dengan hasil studi di dewasa, peneliti tidak menemukan hubungan antara hs-CRP dan berat badan lahir yang kemungkinan dikarenakan usia sampel masih terlalu muda.

Penelitian Turoni $\mathrm{dkk}^{5}$ memperoleh hasil bahwa hubungan negatif antara fungsi endotel dan kekakuan arteri hanya ditemukan pada kelompok BLR. Hasil penelitian ini juga menunjukkan bahwa, meskipun anak-anak dengan BLR mempresentasikan parameter antropometrik, hemodinamik, dan laboratorium dalam batas normal, mereka juga menunjukkan disfungsi endotel prematur. Gangguan vasodilatasi endotel yang terlihat pada penelitian ini berkorelasi dengan peningkatan kadar hs-CRP. Dalam penelitian ini, penanda proinflamasi ini tampaknya lebih terlibat dalam disfungsi endotel awal daripada kekakuan arteri karena kekakuan arteri tidak meningkat pada anak BLR dan tidak ditemukan korelasi hs-CRP dengan kekakuan arteri.

Meskipun BLR diketahui merupakan faktor risiko untuk masalah kardiovaskular di masa dewasa, dampak pada fungsi vaskular di masa anak tidak jelas. Sehubungan dengan fungsi endotel, sesuai dengan penelitian Turoni $\mathrm{dkk},{ }^{5}$ perubahan fungsi endotel dapat terjadi di awal kehidupan (usia 4-6 tahun). Martin $\mathrm{dkk}^{13}$ juga menunjukkan bahwa lingkungan epigenetik yang tidak menguntungkan, terutama malnutrisi dapat menyebabkan terjadinya BLR dan disfungsi endotel pada bayi baru lahir.

Penelitian Shah $\mathrm{dkk}^{14}$ menghubungkan cedera otak pada periode pasca kelahiran dengan peningkatan
TDD pada usia yang lebih tua. Bayi berat lahir rendah tanpa memandang usia gestasi diketahui memiliki tingkat kortisol dan risiko penyakit kardiovaskular yang lebih tinggi sepanjang hidup mereka.

Stock dkk, ${ }^{15}$ dalam penelitiannya pada 930 anak remaja dengan riwayat kelahiran prematur atau $\mathrm{KMK}$, mendapatkan bahwa TDS dan TDD mereka lebih tinggi bermakna dibandingkan dengan kelompok anak yang lahir cukup bulan sesuai masa kehamilan.

Studi potong lintang oleh Rahayu $\mathrm{dkk}^{16}$ mengenai hubungan antara tekanan darah pada anak usia 6-12 tahun dan berat lahir mendapatkan hasil terdapat hubungan peningkatan TDS dan TDD dengan anak riwayat BLR dibandingkan dengan berat lahir normal sehingga dapat disimpulkan berat lahir memiliki hubungan negatif dengan TDS dan TDD.

Penelitian Ting Huang $\mathrm{dkk}^{17}$ mengenai hubungan antara kelahiran prematur dan KMK dengan luaran metabolik pada masa anak dan remaja mendapatkan hasil kelompok usia tersebut memiliki risiko lebih tinggi untuk mengalami hipertensi dibandingkan dengan kontrol anak riwayat lahir cukup bulan sesuai masa kehamilan.

Hubungan antara hs-CRP dengan anak riwayat BLR KMK berusia 9-14 tahun pada penelitian ini adalah korelasi negatif rendah dan analisis hubungan antara TDS maupun TDD dengan hs-CRP berkorelasi sedang sehingga hs-CRP cukup dapat diandalkan untuk penanda peningkatan tekanan darah.

Keterbatasan penelitian ini adalah pengukuran tekanan darah dilakukan hanya pada satu waktu tertentu saja (pagi hari) sehingga dapat terjadi efek white coat. Beberapa penelitian menganjurkan pengukuran tekanan darah ambulatori (24 jam). Pengukuran hs-CRP hanya dilakukan 1 kali. Pada pasien dewasa, American Heart Association (AHA) dan Centers for Disease Control and Prevention (CDC) menganjurkan pengukuran CRP dilakukan 2 kali dengan jarak minimal 2 minggu untuk menentukan risiko kardiovaskular. Penelitian ini tidak mengikutsertakan faktor ibu ataupun faktor lingkungan yang mungkin dapat meningkatkan risiko peningkatan tekanan darah pada anak.

\section{Kesimpulan}

Berdasarkan hasil penelitian dapat disimpulkan bahwa peningkatan kadar hs-CRP pada anak berusia 9 - 14 tahun dengan riwayat BLR KMK berhubungan dengan 
semakin rendahnya berat badan saat lahir. Kadar hsCRP yang tinggi berhubungan dengan tekanan darah yang lebih tinggi.

\section{Daftar pustaka}

1. WHO. Global nutrition targets 2025: low birth weight policy brief. Geneva: World Health Organization; 2014.h.1-8.

2. Kramer MS. The epidemiology of low birthweight. Dalam: Bhatia J, Bhutta ZA, Kalhan SC, penyunting. Maternal and child nutrition: the first 1000 days. Nestle Nutr Inst Workshop Ser 2013;74:1-10.

3. Barker DJP. Developmental origins of adult disease. Am J Nutr 2004;23:588-95.

4. Hughson M, Farris AB, Douglas DR, Hoy WE, Betram JF. Glomerular number and size in autopsy kidneys: the relationship to birth weight. Kidney Int 2003;63:2113-22.

5. Turoni CJ, Chaila Z, Chahla R, Bazan de Casella MC, Peral de Bruno M. Vascular function in children with low birthweight and its relationship with early markers of cardiovascular risk. Horm Res Paediatr 2016;85:396-405.

6. Spencer J, Wang Z, Hoy W. Low birth weight and reduced renal volume in Aboriginal children. Am J Kidney Dis 2001;37:915-20.

7. Brenner BM, Milford EL. Nephron underdosing: a programmed cause of chronic renal allograft failure. Am J Kidney Dis 1993;5:66-72.

8. Reyes L, Manalich R. Long term consequences of low birth weight. Kidney Int 2005;68:107-11.

9. Wasilewska A, Tenderenda E, Janusz KT, Zwierz WZ. High sensitivity C-reactive protein and mean platelet volume in paediatric hypertension. Pediatr Nephrol 2010;25:1519-27.

10. Adakauskine D, Ciginskiene A, Adakauskaite A, Pentiokiniene D, Slapikas R, Ceponiene I. Clinical relevance of high sensitivity C-reactive protein in cardiology. Medicina 2016;52:1-10.

11. Lande MB, Pearson TA, Vermilion RP, Auinger P, Fernandez ID. Elevated blood pressure, race/ethnicity, and C-reactive protein levels in children and adolescents. Pediatrics 2008;122:1252-7.

12. Rondo PH, Pereira JA, Lemos JO. High sensitivity C-reactive protein concentrations, birthweight and cardiovascular risk markers in Brazilian children. Eur J Clin Nutr 2013;67:664-9.

13. Martin H, Lindblad B, Norman M. Endothelial function in newborn infants is related to folate levels and birth weight. Pediatrics 2007;119:1152-8.

14. Shah AB, Hashmi SS, Sahulee R, Pannu H, Gupta-Malhotra M. Characteristics of systemic hypertension in preterm children. J Clin Hyper 2015;17:1-7.

15. Stock K, Schmid A, Griesmaier E, Gande N, Hochmayer C, Knoflach M, dkk. The impact of being born preterm or small for gestational age on early vascular aging in adolescents. J Peds 2018;201:49-54.

16. Rahayu S, Ramayati R, Ramayani OR, Siregar R. Relationship between childhood blood pressure and birth weight. Paediatr Indones 2015;55:117-20.

17. Ting Huang Y, Yu Lin H, Hsing Wang C, Horng Su B, Chen Lin C. Association of preterm birth and small for gestational age with metabolic outcomes in children and adolescents: A population-based cohort study from Taiwan. Paediatr Neonatol 2018;59:147-53. 